\title{
Generation of Cardiomyocytes from New Human Embryonic Stem Cell Lines Derived from Poor-quality Blastocysts
}

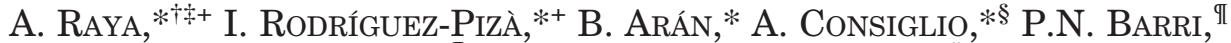 \\ A. VEIGA, *II AND J.C. IZPISÚA BELMONTE*\#" \\ *Center for Regenerative Medicine in Barcelona, 08003 Barcelona, Spain; ' Institució Catalana de Recerca \\ $i$ Estudis Avançats (ICREA); ${ }^{*}$ Networking Center of Biomedical Research in Bioengineering, Biomaterials \\ and Nanomedicine (CIBER-BBN); ${ }^{\S}$ Department of Biomedical Sciences and Biotechnology, Unit of \\ Biochemistry, University of Brescia, 25123 Brescia, Italy; "Departament of Obstetrics, Gynecology, and \\ Reproduction, Institut Universitari Dexeus, Barcelona, Spain; " Gene Expression Laboratory, \\ Salk Institute for Biological Studies, La Jolla, California 92037
}

\begin{abstract}
Human embryonic stem (hES) cells represent a potential source for cell replacement therapy of many degenerative diseases. Most frequently, hES cell lines are derived from surplus embryos from assisted reproduction cycles, independent of their quality or morphology. Here, we show that hES cell lines can be obtained from poor-quality blastocysts with the same efficiency as that obtained from good- or intermediate-quality blastocysts. Furthermore, we show that the self-renewal, pluripotency, and differentiation ability of hES cell lines derived from either source are comparable. Finally, we present a simple and reproducible embryoid body-based protocol for the differentiation of $\mathrm{hES}$ cells into functional cardiomyocytes. The five new hES cell lines derived here should widen the spectrum of available resources for investigating the biology of hES cells and advancing toward efficient strategies of regenerative medicine.
\end{abstract}

hES cells are permanent cell lines derived from preimplantation human embryos, most frequently from the inner cell mass (ICM) of human blastocysts. Since 1998, when the first lines of hES cells were derived (Thomson et al. 1998), numerous hES cell lines have been produced by different laboratories (Allegrucci and Young 2007; Veiga et al. 2007). The two main defining features of these cells are their self-renewal capacity and pluripotency (i.e., their ability to differentiate into cell types of the three embryonic germ layers). Because of these properties, hES cells are thought to hold great potential as a source of cells for therapeutic use. Parkinson's disease, spinal cord injury, diabetes, heart failure, and bone marrow failure are examples of pathological conditions amenable to being treated by means of stem cell transplantation (Gerecht-Nir and Itskovitz-Eldor 2004; Liew et al. 2005; Menasché 2005; Semb 2005). In addition to their potential value as therapeutic agents, hES cells also appear to be a powerful experimental model for studying early human development, a platform to develop and test new drugs and treatment protocols (Pera and Trounson 2004), and an aid for research on human monogenic diseases (Pickering et al. 2003; Verlinsky et al. 2005; Mateizel et al. 2006).

Typically, hES cell lines originate from surplus embryos created during in vitro fertilization (IVF) treatments. Couples reaching an end to their IVF treatments with surplus embryos have a decision to make. These frozen surplus embryos can remain in cryostorage, be made available for adoption, be thawed and discarded, or be donated to research (Lyerly and Faden 2007). It is from

+These authors contributed equally to this work. this latter option that most hES cell lines to date have been derived. IVF programs often use in vitro culture of preimplantation embryos to the blastocyst stage of development to achieve better implantation rates in specific groups of patients (Ménézo et al. 1992; Veiga et al. 1995). Approximately $35 \%$ of cultured human embryos develop successfully to the blastocyst stage but not all of these show good quality morphology. The remainder show retarded or arrested development as well as abnormal morphology due to unequal cell division or cellular fragmentation (Ménézo et al. 1998; Gardner et al. 2000).

Today, the methodology of hES cell derivation is still highly empirical, and various protocols are used in the different steps of the process, including feeder cell preparation (if feeder cells are used), embryo culture, ICM isolation, and initial steps of derivation. It is worth mentioning that an important goal in derivation attempts is to achieve derivation and culture of hES cells under feeder-free (Amit et al. 2004; Klimanskaya et al. 2005) and animal-free (Genbacev et al. 2005; Li et al. 2005; Ellerström et al. 2006; Rajala et al. 2007) conditions, as well as under chemically defined culture conditions (Li et al. 2005; Lu et al. 2006; Ludwig et al. 2006). Moreover, the entire protocol is performed following good manufacturing practice (GMP) conditions necessary for the safe clinical use of hES cells in human therapy. Recent publications have revealed differences among hES cell lines related to the environment to which the cells have been exposed after embryo culture and derivation (Adewumi et al. 2007; Allegrucci and Young 2007).

Here, we present our recent experience at the Center for Regenerative Medicine in Barcelona (CMRB) and describe the successful derivation of five new hES cell lines. Interestingly, three out of the five new hES cell lines were derived from poor-quality blastocysts, underscoring 
the fact that not only embryos of good quality, but those of poor quality can be used for hES cell derivation. Moreover, one of these lines has been adapted to enzymatic passaging, displays extremely high plating efficiency from single cells, and can be routinely maintained on Matrigel- or gelatin-coated plates for extended periods of time ( $>30$ passages) using fibroblast-conditioned media or serum-free chemically defined media without loss of pluripotency or accumulation of karyotypic abnormalities. Finally, we show that functional cardiomyocytes can be reproducibly differentiated from hES cell lines using a modified embryoid body-based protocol, irrespective of the quality of the blastocyst used for their derivation.

\section{DERIVATION OF FIVE NEW HES CELL LINES}

A total of 61 human preembryos, which had been frozen at different stages of development (pronuclear-20, cleavage-35, and blastocyst-6) were used in this study (Table 1). The survival rate after thawing ranged from $80 \%$ for cleavage stage to $50 \%$ for pronuclear stage and averaged $69 \%$ overall. In vitro culture of pronuclear and cleavage-stage embryos resulted in 13 reaching blastocyst stage from the 38 that survived thawing (34\%); 4 of the 6 embryos from blastocyst-stage thaws survived, yielding 17 blastocyst-stage cultures overall. These relatively low rates of survival and blastocyst formation are likely attributed to the substandard freezing protocols that were used at the time that these preembryos were placed into cryostorage. In addition, most supernumerary embryos were frozen irrespective of their quality. If an adequate selection had been performed before freezing, it is probable that derivation efficiency would have achieved higher rates of success (Sjögren et al. 2004).

In total, we obtained 17 blastocysts that were classified according to the criteria (put forth by Stephenson et al. 2006) into three groups: good, intermediate, and poor quality (Table 2). Four of these were graded as good-quality blastocysts, showing expanded morphology, an ICM with compacted cells, and a trophectoderm forming a continuous or almost continuous layer. Four blastocysts were classified as intermediate because they had an ICM with few cells visible and were not compacted. Nine embryos did not have a distinguishable ICM or it appeared degenerated, and these were classified as poor-quality blastocysts. Five of these poor-quality preembryos did not show distinct blastocyst morphology; the ICM was indistinguishable from the trophectoderm and consisted of only a few surviving cells.

Table 1. Summary of results of embryo thawing and derivation

\begin{tabular}{lcccc}
\hline & Pronuclear & Cleavage & Blastocyst & Total \\
\cline { 2 - 5 } Thawed embryo & 20 & 35 & 6 & 61 \\
Embryo survival & $10(50 \%)$ & $28(80 \%)$ & $4(67 \%)$ & $42(69 \%)$ \\
Blastocyst rate & $3(30 \%)$ & $10(36 \%)$ & & \\
$\begin{array}{l}\text { Blastocyst/ICM } \\
\quad \text { seeded }\end{array}$ & 3 & 10 & 4 & 17 \\
Outgrowths & - & 3 & 2 & 5 \\
hES cell lines & - & 3 & 2 & 5 \\
\hline
\end{tabular}

Table 2. Scoring of blastocyst quality

\begin{tabular}{ccclll}
\hline $\begin{array}{l}\text { Embryo } \\
\text { number Expansion }\end{array}$ & ICM & Trophectoderm & $\begin{array}{l}\text { Quality } \\
\text { score }\end{array}$ & Lines \\
\hline 1 & 1 & D & C & poor & \\
2 & 2 & D & C & poor & ES[2] \\
3 & 2 & D & C & poor & \\
4 & 3 & C & C & intermediate & ES[3] \\
5 & 2 & D & C & poor & \\
6 & 3 & B & B & intermediate & \\
7 & 2 & B & A & good & \\
8 & 3 & B & A & good & \\
9 & 3 & C & A & intermediate & \\
10 & 1 & D & C & poor & \\
11 & 2 & D & C & poor & \\
12 & 2 & A & B & good & \\
13 & 2 & C & B & intermediate & \\
14 & 2 & B & A & good & ES[5] \\
15 & 2 & D & B & poor & ES[6] \\
16 & 1 & D & C & poor & ES[4] \\
17 & 1 & D & C & poor & \\
\hline
\end{tabular}

Blastocyst quality was scored following the criteria of Stephenson et al. (2006) with respect to blastocyst expansion: (1) no expansion in overall size, zona pellucida still thick; (2) some expansion in overall size, zona pellucida beginning to thin; (3) full expansion, zona pellucida very thin. ICM appearance ([A] cells compacted, tightly adhered together, and indistinguishable as individual cells; [B] cells less compacted so larger in size, loosely adhered together, some visible as individual cells; [C] very few cells visible, either compacted or loose, may be difficult to completely distinguish from trophectoderm; [D] cells of ICM appear degenerate) and trophectoderm appearance ([A] many small identical cells forming a continuous trophectoderm layer; [B] fewer, larger cells, may not form continuous trophectoderm layer; [C] sparse cells, may be very large, very flat, or appear degenerate).

During the derivation process, the ICM could not be distinguished in some of the blastocysts and thus it was not possible to isolate it. As a consequence, in a first series of experiments, we performed immunosurgery to isolate the ICM only in good-quality blastocysts, whereas those scored as intermediate or poor quality were seeded whole. In a second series of derivations, we avoided ICM isolation altogether for all blastocysts in order to eliminate the use of antibodies and complement from animal origin (Heins et al. 2004; Suss-Toby et al. 2004).

After 4-5 days in culture, a small clump of cells with hES cell morphology (a compact colony structure, a high nuclear-to-cytoplasmic ratio, and prominent nucleoli) (Thomson et al. 1998; Reubinoff et al. 2000) appeared among other cell types of unspecific morphology (Fig. 1A). These compact cell clumps were mechanically dissociated and replated onto fresh feeders after 10-12 days. During that time, the outgrowth of such structures was carefully monitored and the culture media changed on a daily basis. Overall, from the 17 blastocysts seeded, we obtained five hES cell lines (ES[2]-ES[6]; Fig. 1B-C). One line (ES[5]) was derived from one of the four goodquality blastocysts (25\%); one hES cell line (ES[3]) was derived from the four intermediate-quality blastocysts (25\%), and the remaining three lines (ES[2], ES[4], and ES[6]) were derived from the nine poor-quality blastocysts (33\%). The overall derivation efficiency was $29 \%$ and, surprisingly, did not depend on the quality of blastocysts used. This contrasts with the widely held notion that 


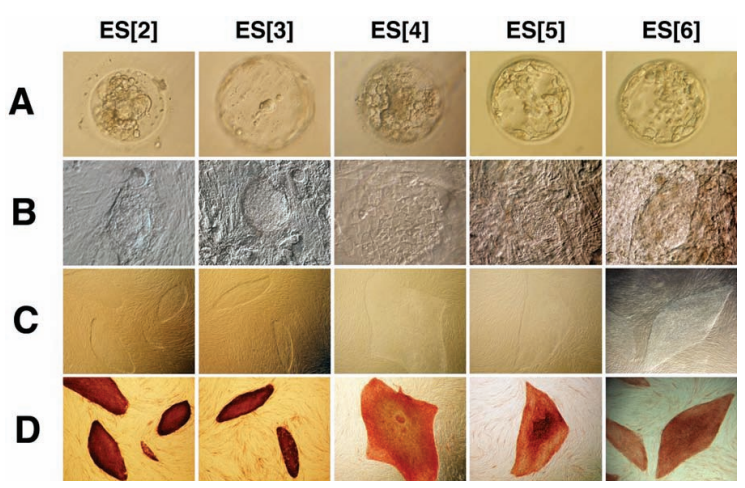

Figure 1. Derivation of five new human embryonic stem cell lines. (A) Blastocysts used for successful hES cell derivations. (B) Initial cellular outgrowth of the successful hES cell derivations, surrounded by trophectoderm derivatives. Note the atypical initial flat growth of the ES[4] line. (C) Morphology of hES cell colonies after 15-20 passages. (D) Analysis of alkaline phosphatase activity on the same colonies as those shown in $C$.

embryo quality is correlated with developmental competence and embryo viability (Alikani et al. 1999) and with previous evidence suggesting that hES cells are more efficiently derived from good-quality embryos (Stojkovic et al. 2004; Oh et al. 2005; Simon et al. 2005; Zhang et al. 2006). Nevertheless, our efficiency in the derivation of $\mathrm{hES}$ cell lines from poor-quality blastocycts is consistent with previous studies reporting the derivation of four lines from 19 discarded embryos (21\% derivation efficiency) (Mitalipova et al. 2003) and two lines from 19 blastocysts derived from day-3 embryos with low morphological scores (10\% derivation efficiency) (Chen et al. 2005).

\section{CHARACTERIZATION OF THE NEW HES CELL LINES}

Karyotype analysis, human leukocyte antigen (HLA) typing, expression of pluripotency-associated markers, and evaluation of pluripotency in vitro and in vivo were used to characterize all five $\mathrm{hES}$ cell lines. A summary of the results obtained from these analyses is presented in Table 3.

The five hES cell lines were positive for all pluripotency markers tested, displaying high levels of alkaline phosphatase (Fig. 1D) and telomerase activity (data not shown) and high levels of Oct4, Nanog, Sox2, SSEA-3, SSEA-4, TRA-1-60, and TRA-1-81 immunoreactivity (Fig. 2 and data not shown). All five lines displayed a normal karyotype (46, XY; data not shown). We are currently investigating the possible significance of a male karyotype for all five lines derived in this study. Four hES cell lines (ES[2]-[4] and ES[6]) have been continuously kept in culture for more than 50 passages $(>150$ population doublings; Table 3) without evident changes in their growth characteristics, expression of pluripotency-associated markers, or karyotype (data not shown).

All five hES cell lines formed teratomas in severe combined immunodeficient (SCID) beige mice. The tumors contained derivatives from the three embryonic germ layers, such as respiratory epithelium (Fig. 3A-B and data not
Table 3. Summary of characterization analyses of the five new

\begin{tabular}{|c|c|c|c|c|c|}
\hline & $\mathrm{ES}[2]$ & $\mathrm{ES}[3]$ & ES[4] & ES[5] & $\mathrm{ES}[6]$ \\
\hline Karyotype & $46, X Y$ & $46, X Y$ & $46, X Y$ & $46, X Y$ & $46, \mathrm{XI}$ \\
\hline Alkaline phosphatase & + & + & + & + & + \\
\hline Telomerase & + & + & + & + & + \\
\hline HLA typing & done $^{\mathrm{a}}$ & done $^{a}$ & done $^{\mathrm{a}}$ & done $^{\mathrm{a}}$ & done $^{\mathrm{a}}$ \\
\hline MDF & done $^{a}$ & done $^{a}$ & done $^{\mathrm{a}}$ & done $^{a}$ & done $^{\mathrm{a}}$ \\
\hline Number of passages & 50 & 65 & 51 & 50 & 78 \\
\hline \multicolumn{6}{|l|}{ Pluripotency markers } \\
\hline SSEA-3 & + & + & + & + & + \\
\hline SSEA-4 & + & + & + & + & + \\
\hline TRA-1-60 & + & + & + & + & + \\
\hline TRA-1-81 & + & + & + & + & + \\
\hline Oct-4 & + & + & + & + & + \\
\hline NANOG & + & + & + & + & + \\
\hline Sox-2 & + & + & + & + & + \\
\hline SSEA-1 & - & - & - & - & - \\
\hline Freezing/thawing & + & + & + & + & + \\
\hline \multicolumn{6}{|l|}{ Pluripotency } \\
\hline \multicolumn{6}{|l|}{ In vitro } \\
\hline Endoderm & + & + & + & + & + \\
\hline Ectoderm & + & + & + & + & + \\
\hline Mesoderm & + & + & + & + & + \\
\hline \multicolumn{6}{|l|}{ In vivo } \\
\hline Endoderm & + & + & + & + & + \\
\hline Ectoderm & + & + & + & + & + \\
\hline Mesoderm & + & + & + & + & + \\
\hline
\end{tabular}

Definitions: (HLA) Human leukocyte antigen; (MDF) microsatellite DNA fingerprinting; (+) positive/present; (-) negative. ${ }^{a}$ Full details are available upon request.

shown), cartilage (Fig. 3C-D and data not shown), or organized structures that stained positive for neural $\beta$-tubulin III, $\alpha$-fetoprotein, or $\alpha$-actinin (Fig. 3E-H and data not shown).

To ascertain the ability of hES cell lines to differentiate in vitro, we initially induced the formation of embryoid bodies from colony fragments maintained in suspension for 3-4 days in hES cell media. Under these conditions, embryoid bodies were formed in a reproducible manner, and we could overcome the characteristic difficulty of hES cells to grow as aggregates (Reubinoff et al. 2000). Withdrawal of basic fibroblast growth factor (bFGF) during this phase resulted in extensive cell death and failure to maintain initial cell aggregates, as has been previously reported (Reubinoff et al. 2000). After 3-4 days of growth in hES cell media, embryoid bodies generated in this way were plated onto gelatin-coated plates and allowed to undergo further differentiation by removal of bFGF and the addition of serum. Endoderm derivatives displaying strong $\alpha$-fetoprotein immunoreactivity were readily observed after 2-3 weeks in all five hES cell lines (Fig. 4A and data not shown). However, neuroectoderm derivatives were obtained at a very low frequency under these conditions. To promote differentiation of hES cells toward neuronal fates, we adapted a protocol of coculture with the stromal cell line PA6 that has been described to enhance neural differentiation of mouse ES cells (Kitajima et al. 2005). All five hES cell lines cocultured with PA6 cells gave rise to differentiated cells with the morphology of mature neurons that expressed high levels of $\beta$-tubulin III (Fig. 4B and data not shown). 


\section{ES[2]}
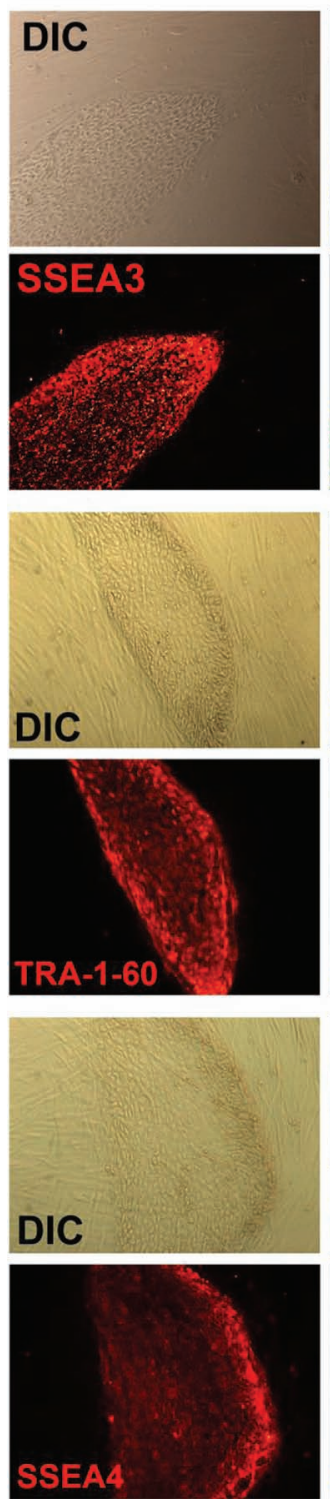
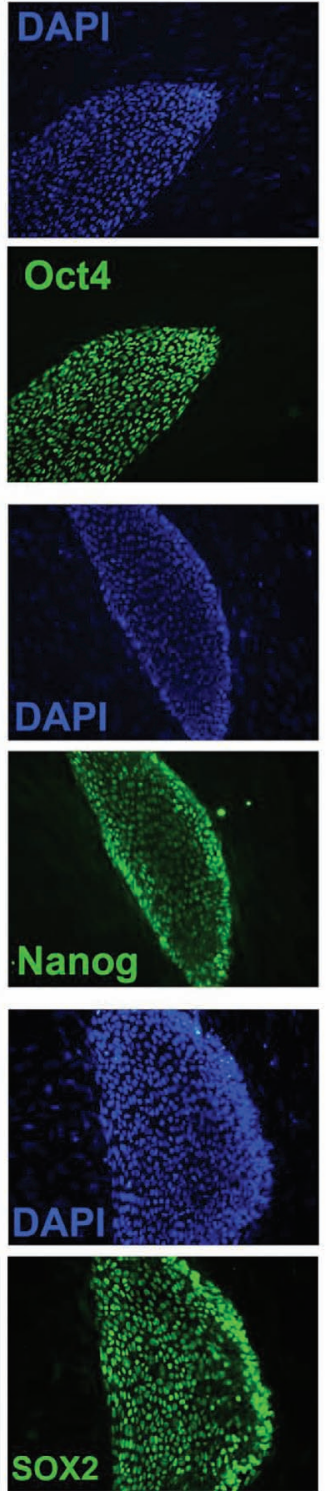

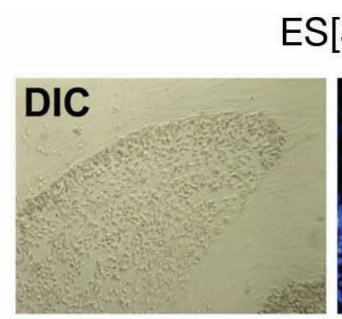

ES[3]
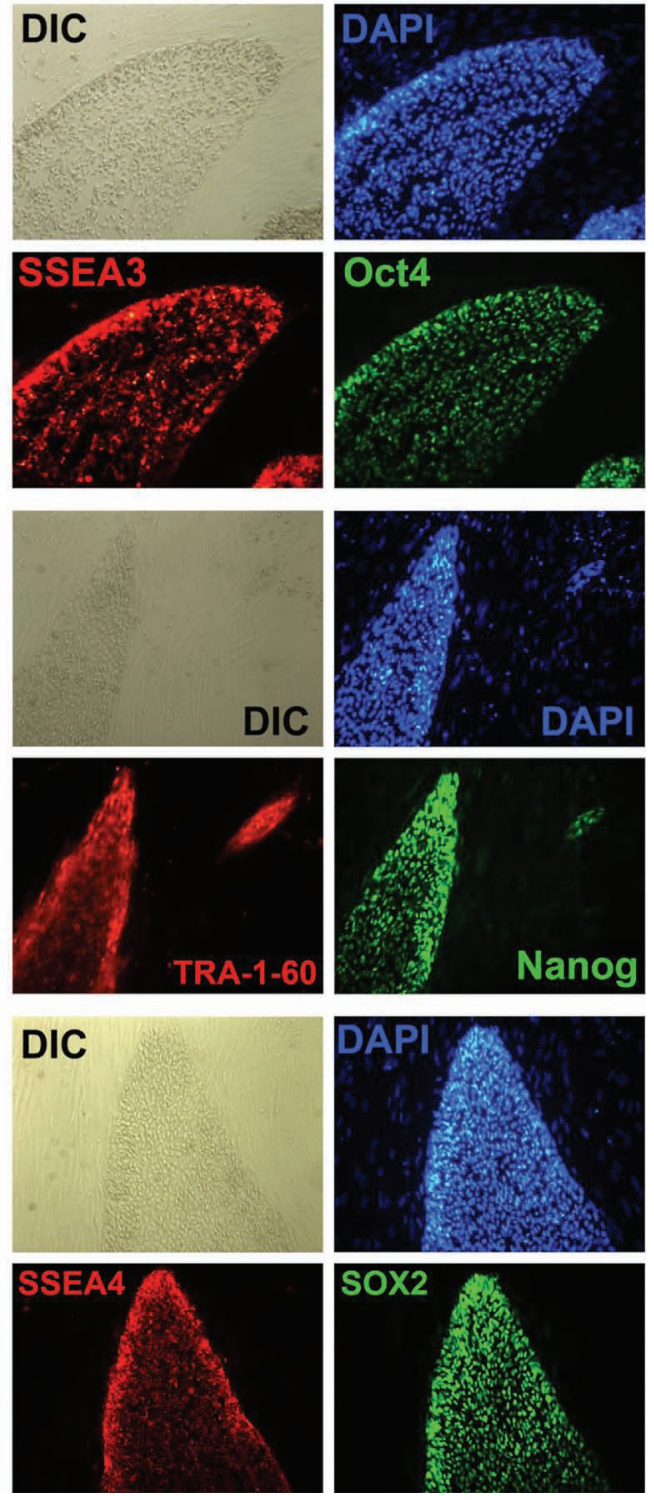

Figure 2. Expression of pluripotency-associated markers. Morphology (as shown by differential interference contrast [DIC]) and immunofluorescence localization of SSEA3, Oct4, TRA-1-60, Nanog, SSEA4, and SOX2 in colonies of ES[2] and ES[3] lines. Cell nuclei were counterstained with DAPI.

\section{EMBRYOID BODY-BASED CARDIAC DIFFERENTIATION OF HES CELLS}

In contrast to mouse ES cells, the differentiation of hES cells toward cardiomyocytes is notoriously inefficient (Reubinoff et al. 2000), particularly more so when using embryoid body-based differentiation protocols (Kehat et al. 2001; Laflamme et al. 2005, 2007). Alternatively, coculture of hES cells with mouse visceral endoderm-like END-2 cells has been shown to result in robust induction of cardiomyocyte differentiation (Mummery et al. 2003). To characterize the ability of the new hES cell lines to differentiate into cardiomyocytes in vitro, and in an attempt to establish differentiation protocols that do not rely on coculture systems, we initially set out to analyze the pres- ence of heart muscle derivatives in embryoid bodies allowed to differentiate in serum-containing media for 2-4 weeks. In contrast to previous studies (Xu et al. 2002), but in agreement with observations from different laboratories using a variety of hES cell lines (Kehat et al. 2001; Laflamme et al. 2005, 2007), we did not observe rhythmically beating cells under these conditions in any of the five new hES cell lines (Fig. 5A and data not shown). We next analyzed the effect of ascorbic acid, because it has been shown that this compound enhances the cardiac differentiation of mouse ES cells (Takahashi et al. 2003) and potentiates the cardiogenic effect of END-2-hES cell cocultures (Passier et al. 2005). The supplementation of the differentiation medium with $100 \mu \mathrm{M}$ ascorbic acid resulted in approximately $20 \%$ of the embryoid bodies generated 


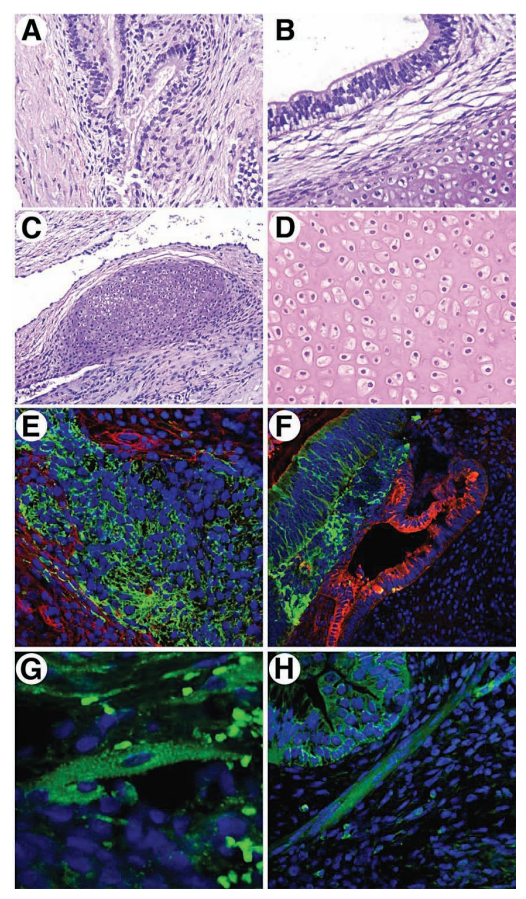

Figure 3. Pluripotency of hES cells in vivo. Hematoxylin and eosin staining $(A-D)$ and immunofluorescence localization $(E-H)$ in paraffin sections of teratomas induced by injecting $\mathrm{ES}[2](A, C, E, G)$ or $\mathrm{ES}[3](B, D, F, H)$ cells into severe combined immunodeficient (SCID) beige mice. Histologically recognizable structures include respiratory epithelia $(A, B)$ and cartilage formations $(C, D)$. $(E, F)$ Neuroectoderm and endoderm derivatives were detected by strong immunoreactivity for $\beta$-tubulin III (green channel) and $\alpha$-fetoprotein (red channel), respectively. $(G, H)$ Mesoderm derivatives were detected by strong immunoreactivity for $\alpha$-actinin (green channel). Cell nuclei were counterstained with DAPI in $E-H$.

from any of the five hES cell lines displaying rhythmically beating areas (Fig. 5B and data not shown) that stained strongly positive for cardiac $\alpha$-actinin (Fig. 5C and data not shown). Our results show that reproducible cardiac differentiation of hES cells can be obtained using relatively simple in vitro protocols and provide a valuable experi-
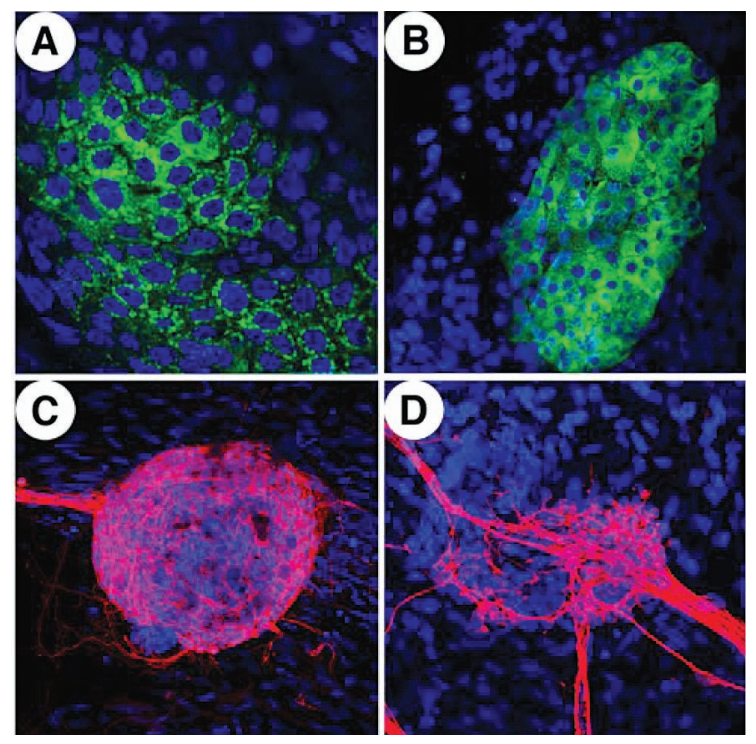

Figure 4. In vitro differentiation of endoderm and neuroectoderm derivatives. $\mathrm{ES}[2](A, C)$ and $\mathrm{ES}[3](B, D)$ cells readily generate endoderm derivatives after embryoid body-based differentiation protocols $(A, B)$, as evidenced by glandular structures immunoreactive for $\alpha$-fetoprotein (green channel) and differentiated cells with morphology of mature neurons that stain positive for $\beta$-tubulin III (red channel) after coculture with PA6 cells $(C, D)$. Cell nuclei were counterstained with DAPI.

mental platform to further optimize such protocols for the directed generation of large quantities of human cardiomyocytes as well as for exploring the mechanisms that control cardiomyocyte differentiation.

\section{ESTABLISHMENT OF ENZYMATICALLY DISPERSABLE HES CELL LINES}

Human ES cells typically display very low plating efficiency when passaged as single cells (Amit et al. 2000) and therefore require mechanical or mild enzymatic dissociation of cell clumps. These procedures are time-con-
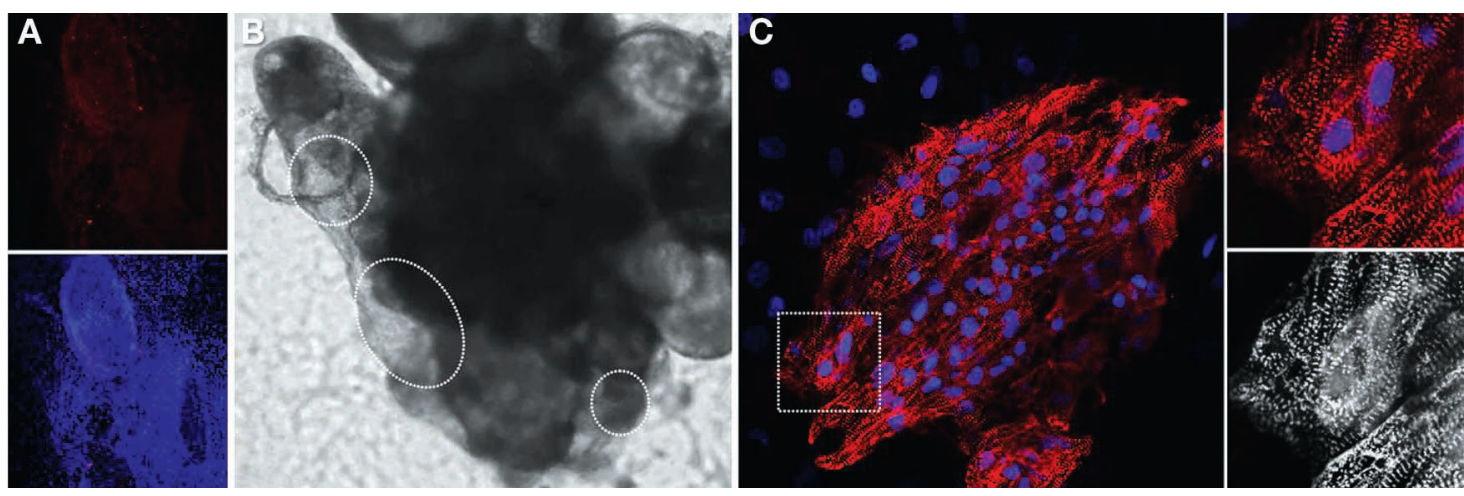

Figure 5. Embryoid body-based in vitro differentiation of hES cells into cardiomyocytes. (A) Embryoid bodies of ES[3] cells after 3 weeks of differentiation in serum-containing media fail to differentiate into cardiomyocytes, as evidenced by the absence of $\alpha$-actinin immunoreactivity (red channel). Cell nuclei were counterstained with DAPI in the lower panel. $(B, C)$ Addition of ascorbic acid to the differentiation medium results in cardiomyocyte differentiation of ES[3]-derived embryoid bodies, as shown by the appearance of rhythmically beating areas, encircled in $B$, and strong immunoreactivity for $\alpha$-actinin (red channel in $C$ ). A higher magnification of the area marked in $C$ is shown in the right panels to better appreciate the sarcomeric striations of the $\alpha$-actinin staining. Cell nuclei were counterstained with DAPI in $C$. 
suming, result in variable degrees of cell differentiation during hES cell culture maintenance, and make the establishment of genetically modified hES cell clones difficult. The derivation of hES cell lines that can be routinely passaged as single cells (Cowan et al. 2004) and the adaptation to single-cell dissociation of preexisting hES cell lines (Ellerström et al. 2007) are thus likely to facilitate the maintenance of undifferentiated hES cells and their experimental manipulation.

For these reasons, we attempted to establish subclones of hES cells that displayed high plating efficiency after single-cell trypsinization. Subclones were particularly easily adapted from early-passage (passage 3 or 4) ES[4] cells and have been maintained for more than 40 passages on feeders after single-cell dissociation (scES[4]). Furthermore, scES[4] cells can also be propagated for extended periods of time in fibroblast-free cultures using feeder-conditioned hES cell media and Matrigel- or gelatin-coated plates. It should be noted that, even though it has been suggested that such culture adaptations may increase the propensity of hES cells to accumulate karyotypic abnormalities (Enver et al. 2005; Baker et al. 2007), scES[4] cells continuously maintained in our laboratory for more than 30 passages under feeder-free conditions using Matrigel retain a normal karyotype and pluripotency in vivo and in vitro (data not shown). Finally, scES[4] cells have also been easily adapted to commercially available serum-free, chemically defined media $\left(\mathrm{mTeSR}^{\mathrm{TM}} 1\right.$ or STEMPRO ${ }^{\circledR}$ hESC SFM) and have been maintained undifferentiated for more than 10 passages on Matrigel- or gelatin-coated plates.

\section{METHODS}

Source of human preembryos. Human preimplantation embryos were specifically donated for this research project by couples undergoing IVF cycles at the Institut Universitari Dexeus (Barcelona). Embryos were used for the present study with the informed consent of the couples, following the protocol previously approved by the Institutional Ethics Committee on Clinic Investigation and the Spanish competent authorities (Comisión de Seguimiento y Control de la Donación de Células y Tejidos Humanos del Instituto de Salud Carlos III). Derivations were performed at the Stem Cell Bank of the Center of Regenerative Medicine in Barcelona.

Embryos were thawed using Vitrolife thawing media, Thaw-kit 1, or Thaw-kit Blast (Vitrolife, Göteborg, Sweden), depending on the embryo stage and according to manufacturer instructions.

Derivation of hES cell lines. Early-cleavage embryos were cultured in G1.2 medium (Vitrolife, Göteborg, Sweden) until day 3 and then in G2.2 medium (Vitrolife) to the blastocyst stage. Embryos thawed at the blastocyt stage were cultured in G2.2 medium overnight to allow for reexpansion. Blastocysts were classified according to criteria reported elsewhere (Stephenson et al. 2006).

The zona pellucida was removed with $5 \mathrm{mg} / \mathrm{ml}$ pronase (Roche) or with Tyrode's acid (Medicult). Fragments and degenerated cells were gently removed with a pulled
Pasteur pipette (Humagen Fertility Diagnostics). When performed, immunosurgery for ICM isolation was performed according to published protocols (Solter and Knowles 1975). Whole blastocysts or isolated ICMs were plated on top of irradiated (55Gy) human foreskin fibroblasts (CCD1112Sk ATCC), seeded at a density of $7 \times 10^{4}$ cells $/ \mathrm{cm}^{2}$ on IVF dishes (Falcon, Becton Dickinson) coated with $0.1 \%$ gelatin (Chemicon) and cultured further at $37^{\circ} \mathrm{C}$ and $5 \% \mathrm{CO}_{2}$ in hES cell media consisting of KO-Dulbecco's modified Eagle's medium (DMEM) supplemented with 20\% KO-Serum Replacement (Invitrogen), 2 mм GlutaMAX (Invitrogen), $50 \mu \mathrm{M}$ 2-mercaptoethanol (Invitrogen), nonessential amino acids (Cambrex), $8 \mathrm{ng} / \mathrm{ml} \mathrm{bFGF} \mathrm{(Invitrogen),} \mathrm{and} \mathrm{penicillin-}$ streptomycin (Invitrogen). Outgrowths were mechanically dissociated into small clumps after 10-12 days using a $150-\mu \mathrm{m}$-diameter plastic pipette (The Stripper, Midatlantic Diagnostics) and replated onto a fresh feeder layer.

Propagation of hES cell lines. Individual undifferentiated colonies were mechanically dissociated into small clumps using a $150-\mu \mathrm{m}$-diameter plastic pipette and replated every 5-7 days. In some cases, single-cell suspensions were prepared after enzymatic dispersion (0.05\% Trypsin/EDTA, Invitrogen) and plated at 1:5-1:10 dilutions onto feeder layers or on plates coated with Matrigel (Becton Dickinson) diluted 1:15 with KO-DMEM or $0.1 \%$ gelatin. In feeder-free cultures, we used hES cell media preconditioned by feeders. The following commercially available serum-free, chemically defined media were also assayed following manufacturer directions: $\mathrm{mTeSR}^{\mathrm{TM}} 1$ (StemCell Technologies) and STEMPRO ${ }^{\circledR}$ hESC SFM (Invitrogen).

Karyotyping was performed after incubating colonies for 30 minutes in a 1:500 dilution of Colcemid (Invitrogen) by the G-banding method and imaged and processed using the software CytoVision (Applied Imaging, Olympus). A minimum of 15 metaphases were analyzed for each line.

Colonies were also periodically selected and cryopreserved in cryotube vials (Nunc, Roskilde) in 90\% fetal bovine serum (FBS) and 10\% dimethylsulfoxide (DMSO) (Sigma-Aldrich) at a cooling rate of $1^{\circ} \mathrm{C}$ per minute and stored in liquid nitrogen. After thawing at $37^{\circ} \mathrm{C}$, some colonies were plated on new feeder layers in hES medium to assess freezing/thawing survival.

In vitro differentiation. Embryoid bodies (EBs) were generated from large colony fragments obtained by mechanical splitting with a finely drawn Pasteur pipette or by treatment of confluent hES cell cultures with 1 $\mathrm{mg} / \mathrm{ml}$ collagenase IV (Invitrogen) for 10 minutes at $37^{\circ} \mathrm{C}$. Colony fragments were maintained in nonadherent dishes for 3-4 days in hES medium. Embryoid bodies were then plated in $0.1 \%$ gelatin-coated glass chamber slides and cultured in differentiation medium (DMEM supplemented with $20 \%$ fetal bovine serum, $2 \mathrm{~mm}$ GlutaMAX, $100 \mu \mathrm{M}$ 2-mercaptoethanol, nonessential amino acids, and penicillin-streptomycin) for 2-3 weeks. Neuronal differentiation of hES cells was induced by 
coculture with the stromal cell line PA6 for 3-5 weeks (Kitajima et al. 2005). Differentiation into mesoderm derivatives was enhanced by supplementing the differentiation medium with $100 \mu \mathrm{M}$ ascorbic acid (SigmaAldrich).

Teratoma formation. Approximately $10^{6} \mathrm{hES}$ cells were resuspended in 20-40 $\mu \mathrm{l}$ of hES cell media and injected intramuscularly into the gastrocnemius of SCID beige mice (Charles River Laboratories). Eight weeks after cell injection, mice were sacrificed and tumors were processed and analyzed following conventional immunohistochemistry protocols. All animal experiments were conducted following experimental protocols previously approved by the Institutional Ethics Committee on Experimental Animals, in full compliance with Spanish and European laws and regulations.

Immunofluorescence. Cells grown on chamber slides (LabTek, Nunc) were washed with PBS and fixed with 4\% paraformaldehyde for 15 minutes at $4^{\circ} \mathrm{C}$. We used the following primary antibodies for immunofluorescence: mouse anti-Oct4 (1:500, Santa Cruz Biotechnology), rabbit anti-Sox2 (1:100, Chemicon), rabbit anti-Nanog (1:500, Abcam), rat anti-SSEA-3, mouse anti-SSEA-4, mouse anti-TRA-1-60, mouse anti-TRA-1-81 (1:10, Chemicon), mouse anti- $\alpha$-actinin (1:100, Sigma-Aldrich), mouse anti$\beta$-tubulin III (1:1000, Covance), and rabbit anti- $\alpha$-fetoprotein (1:400, Dako). Incubation with primary antibody was for 24 hours at $4^{\circ} \mathrm{C}$. Incubation with FITC-, Cy2-, or Cy3conjugated secondary antibodies (1:200, Jackson ImmunoResearch) was for 2 hours at room temperature followed by counterstaining with 4'-6-diamidino-2-phenylindole (DAPI) (10 mg/ml, Sigma-Aldrich).

Alkaline phosphatase activity was measured using the Alkaline Phosphatase Red Membrane Substrate (SigmaAldrich) after fixation with $4 \%$ paraformaldehyde for 2 minutes. Telomerase activity was detected using the TRAPeze Telomerase Detection Kit (Chemicon International) following manufacturer directions.

Molecular typing. HLA typing of hES cell lines was performed by sequence-based typification (SBT) with the AlleleSEQR HLA Sequencing Kit (Atria Genetics). Microsatellite DNA fingerprinting was performed using multiplex polymerase chain reaction of nine microsatellites or short tandem repeats (STRs) plus amelogenine gene using AmplF1STR Profiler Plus Kit (Applied Biosystems).

\section{CONCLUSIONS}

The five new hES cell lines derived in this study provide valuable tools for investigating the mechanisms of ES cell self-renewal, pluripotency, and differentiation toward specific cell types. ES[2] and ES[3] are currently available to interested researchers through the Spanish Stem Cell Bank (http://www.isciii.es/htdocs/terapia/ terapia_lineas.jsp). The remaining three lines (ES[4], $\mathrm{ES}[5]$, and ES[6]) are in the process of being registered and deposited and will soon be similarly available.

\section{ACKNOWLEDGMENTS}

We are grateful to Joana Visa for help with teratoma formation assays, Vicenç Català and Esther Cuatrecases for help and advice with karyotyping, Ricardo Pujol and Eduard Palou for HLA typing, and the personnel of the Institut Universitari Dexeus, especially Marta Luna, for assistance with embryo handling. We are indebted to Travis Berggren and members of the Belmonte laboratory for comments on the manuscript. We thank Meritxell Carrió, Yolanda Muñoz, and Yvonne Richaud for excellent technical assistance in hES cell culture, and Mercé Martí for expert assistance in confocal microscopy. I.R.-P. is a recipient of a MEC predoctoral fellowship. This work was partially supported by Fondo de Investigaciones Sanitarias grants RETIC-RD06/0010/0016 (to J.C.I.B.), PI052847 (to A.V.), and CP05/00294 and PI061897 (to A.C.), Ministerio de Educación y Ciencia grants BFU2006-12247 (to J.C.I.B.) and BFU2006-12251 (to A.R.), AGAUR grant 2005SGR00331 (to J.C.I.B.), European Commission "Marie-Curie Reintegration Grant" MIRG-CT-2007046523 (to A.R.), Marató de TV3 grant 063430 (to J.C.I.B.), and Fundación Cellex grant (to J.C.I.B.).

\section{REFERENCES}

Adewumi, O., Aflatoonian, B., Ahrlund-Richter, L., Amit, M., Andrews, P.W., Beighton, G., Bello, P.A., Benvenisty, N., Berry, L.S., Bevan, S., et al. 2007. Characterization of human embryonic stem cell lines by the International Stem Cell Initiative. Nat. Biotechnol. 25: 803-816.

Alikani, M., Cohen, J., Tomkin, G., Garrisi, G.J., Mack C., and Scott, R.T. 1999. Human embryo fragmentation in vitro and its implications for pregnancy and implantation. Fertil. Steril. 71: 836-842.

Allegrucci, C. and Young, L.E. 2007. Differences between human embryonic stem cell lines. Hum. Reprod. Update 13: 103-120.

Amit, M., Shariki, C., Margulets, V., and Itskovitz-Eldor, J. 2004. Feeder layer- and serum-free culture of human embryonic stem cells. Biol. Reprod. 70: 837-845.

Amit, M., Carpenter, M.K., Inokuma, M.S., Chiu, C.P., Harris, C.P., Waknitz, M.A., Itskovitz-Eldor, J., and Thomson, J.A. 2000. Clonally derived human embryonic stem cell lines maintain pluripotency and proliferative potential for prolonged periods of culture. Dev. Biol. 227: 271-278.

Baker, D.E., Harrison, N.J., Maltby, E., Smith, K., Moore, H.D., Shaw, P.J., Heath, P.R., Holden, H., and Andrews, P.W. 2007. Adaptation to culture of human embryonic stem cells and oncogenesis in vivo. Nat. Biotechnol. 25: 207-215.

Chen, H., Qian, K., Hu, J., Liu, D., Lu, W., Yang, Y., Wang, D., Yan, H., Zhang, S., and Zhu, G. 2005. The derivation of two additional human embryonic stem cell lines from day 3 embryos with low morphological scores. Hum. Reprod. 20: 2201-2206.

Cowan, C.A., Klimanskaya, I., McMahon, J., Atienza, J., Witmyer, J., Zucker, J.P., Wang, S., Morton, C.C., McMahon, A.P., Powers, D., and Melton, D.A. 2004. Derivation of embryonic stem-cell lines from human blastocysts. N. Engl. J. Med. 350: 1353-1356.

Ellerström, C., Strehl, R., Noaksson, K., Hyllner, J., and Semb, H. 2007. Facilitated expansion of human embryonic stem cells by single-cell enzymatic dissociation. Stem Cells 25: $1690-1696$

Ellerström, C., Strehl, R., Moya, K., Andersson, K., Bergh, C., Lundin, K., Hyllner, J., and Semb, H. 2006. Derivation of a xeno-free human embryonic stem cell line. Stem Cells 24: 2170-2176.

Enver, T., Soneji, S., Joshi, C., Brown, J., Iborra, F., Orntoft, T., Thykjaer, T., Maltby, E., Smith, K., Dawud, R.A., et al. 2005. 
Cellular differentiation hierarchies in normal and cultureadapted human embryonic stem cells. Hum. Mol. Genet. 14: 3129-3140.

Gardner, D.K., Lane, M., Stevens, J., Schlenker, T., and Schoolcraft, W.B. 2000. Blastocyst score affects implantation and pregnancy outcome: Towards a single blastocyst transfer. Fertil. Steril. 73: 1155-1158.

Genbacev, O., Krtolica, A., Zdravkovic, T., Brunette, E., Powell, S., Nath, A., Caceres, E., McMaster, M., McDonagh, S., Li, Y., et al. 2005. Serum-free derivation of human embryonic stem cell lines on human placental fibroblast feeders. Fertil. Steril. 83: 1517-1529.

Gerecht-Nir, S. and Itskovitz-Eldor, J. 2004. Human embryonic stem cells: A potential source for cellular therapy. Am. J. Transplant. (suppl. 6) 4: 51-57.

Heins, N., Englund, M.C., Sjoblom, C., Dahl, U., Tonning, A., Bergh, C., Lindahl, A., Hanson, C., and Semb, H. 2004. Derivation, characterization, and differentiation of human embryonic stem cells. Stem Cells 22: 367-376.

Kehat, I., Kenyagin-Karsenti, D., Snir, M., Segev, H., Amit, M., Gepstein, A., Livne, E., Binah, O., Itskovitz-Eldor, J., and Gepstein, L. 2001. Human embryonic stem cells can differentiate into myocytes with structural and functional properties of cardiomyocytes. J. Clin. Invest. 108: 407-414.

Kitajima, H., Yoshimura, S., Kokuzawa, J., Kato, M., Iwama, T., Motohashi, T., Kunisada, T., and Sakai, N. 2005. Culture method for the induction of neurospheres from mouse embryonic stem cells by coculture with PA6 stromal cells. $J$. Neurosci. Res. 80: 467-474.

Klimanskaya, I., Chung, Y., Meisner, L., Johnson, J., West, M.D., and Lanza, R. 2005. Human embryonic stem cells derived without feeder cells. Lancet 365: 1636-1641.

Laflamme, M.A., Gold, J., Xu, C., Hassanipour, M., Rosler, E., Police, S., Muskheli, V., and Murry, C.E. 2005. Formation of human myocardium in the rat heart from human embryonic stem cells. Am. J. Pathol. 167: 663-671.

Laflamme, M.A., Chen, K.Y., Naumova, A.V., Muskheli, V., Fugate, J.A., Dupras, S.K., Reinecke, H., Xu, C., Hassanipour, M., Police, S., et al. 2007. Cardiomyocytes derived from human embryonic stem cells in pro-survival factors enhance function of infarcted rat hearts. Nat. Biotechnol. 25: 10151024.

Li, T., Zhou, C.Q., Mai, Q.Y., and Zhuang, G.L. 2005. Establishment of human embryonic stem cell line from gamete donors. Chin. Med. J. 118: 116-122.

Liew, C.G., Moore, H., Ruban, L., Shah, N., Cosgrove, K., Dunne, M., and Andrews, P. 2005. Human embryonic stem cells: Possibilities for human cell transplantation. Ann. Med. 37: 521-532.

Lu, J., Hou, R., Booth, C.J., Yang, S.H., and Snyder, M. 2006. Defined culture conditions of human embryonic stem cells. Proc. Natl. Acad. Sci. 103: 5688-5693.

Ludwig, T.E., Levenstein, M.E., Jones, J.M., Berggren, W.T., Mitchen, E.R., Frane, J.L., Crandall, L.J., Daigh, C.A., Conard, K.R., Piekarczyk, M.S., Llanas, R.A., and Thomson, J.A. 2006. Derivation of human embryonic stem cells in defined conditions. Nat. Biotechnol. 24: 185-187.

Lyerly, A.D. and Faden, R.R. 2007. Embryonic stem cells. Willingness to donate frozen embryos for stem cell research. Science 317: 46-47.

Mateizel, I., De Temmerman, N., Ullmann, U., Cauffman, G., Sermon, K., Van de Velde, H., De Rycke, M., Degreef, E., Devroey, P., Liebaers, I., and Van Steirteghem, A. 2006. Derivation of human embryonic stem cell lines from embryos obtained after IVF and after PGD for monogenic disorders. Hum. Reprod. 21: 503-511.

Menasché, P. 2005. The potential of embryonic stem cells to treat heart disease. Curr. Opin. Mol. Ther. 7: 293-299.

Ménézo, Y., Veiga, A., and Benkhalifa, M. 1998. Improved methods for blastocyst formation and culture. Hum. Reprod. (suppl. 4) 13: 256-265.

Ménézo, Y., Hazout, A., Dumont, M., Herbaut, N., and Nicollet, B. 1992. Coculture of embryos on Vero cells and transfer of blastocysts in humans. Hum. Reprod. (suppl. 1) 7: 101-106.
Mitalipova, M., Calhoun, J., Shin, S., Wininger, D., Schulz, T., Noggle, S., Venable, A., Lyons, I., Robins, A., and Stice, S. 2003. Human embryonic stem cell lines derived from discarded embryos. Stem Cells 21: 521-526.

Mummery, C., Ward-van Oostwaard, D., Doevendans, P., Spijker, R., van den Brink, S., Hassink, R., van der Heyden, M., Opthof, T., Pera, M., de la Riviere, A.B., Passier, R., and Tertoolen, L. 2003. Differentiation of human embryonic stem cells to cardiomyocytes: Role of coculture with visceral endoderm-like cells. Circulation 107: 2733-2740.

Oh, S.K., Kim, H.S., Ahn, H.J., Seol, H.W., Kim, Y.Y., Park, Y.B., Yoon, C.J., Kim, D.W., Kim, S.H., and Moon, S.Y. 2005. Derivation and characterization of new human embryonic stem cell lines: SNUhES1, SNUhES2, and SNUhES3. Stem Cells 23: 211-219.

Passier, R., Oostwaard, D.W., Snapper, J., Kloots, J., Hassink, R.J., Kuijk, E., Roelen, B., de la Riviere, A.B., and Mummery, C. 2005. Increased cardiomyocyte differentiation from human embryonic stem cells in serum-free cultures. Stem Cells 23: 772-780.

Pera, M.F. and Trounson, A.O. 2004. Human embryonic stem cells: Prospects for development. Development 131: 55155525 .

Pickering, S.J., Braude, P.R., Patel, M., Burns, C.J., Trussler, J., Bolton, V., and Minger, S. 2003. Preimplantation genetic diagnosis as a novel source of embryos for stem cell research. Reprod. Biomed. Online 7: 353-364.

Rajala, K., Hakala, H., Panula, S., Aivio, S., Pihlajamaki, H., Suuronen, R., Hovatta, O., and Skottman, H. 2007. Testing of nine different xeno-free culture media for human embryonic stem cell cultures. Hum. Reprod. 22: 1231-1238.

Reubinoff, B.E., Pera, M.F., Fong, C.Y., Trounson, A., and Bongso, A. 2000. Embryonic stem cell lines from human blastocysts: Somatic differentiation in vitro. Nat. Biotechnol. 18: 399-404.

Semb, H. 2005. Human embryonic stem cells: Origin, properties and applications. APMIS 113: 743-750.

Simon, C., Escobedo, C., Valbuena, D., Genbacev, O., Galan, A., Krtolica, A., Asensi, A., Sanchez, E., Esplugues, J., Fisher, S., and Pellicer, A. 2005. First derivation in Spain of human embryonic stem cell lines: Use of long-term cryopreserved embryos and animal-free conditions. Fertil. Steril. 83: 246-249.

Sjögren, A., Hardarson, T., Andersson, K., Caisander, G., Lundquist, M., Wikland, M., Semb, H., and Hamberger, L. 2004. Human blastocysts for the development of embryonic stem cells. Reprod. Biomed. Online 9: 326-329.

Solter, D. and Knowles, B.B. 1975. Immunosurgery of mouse blastocyst. Proc. Natl. Acad. Sci. 72: 5099-5102.

Stephenson, E.L., Braude, P.R., and Mason, C. 2006. Proposal for a universal minimum information convention for the reporting on the derivation of human embryonic stem cell lines. Regen. Med. 1: 739-750.

Stojkovic, M., Lako, M., Stojkovic, P., Stewart, R., Przyborski, S., Armstrong, L., Evans, J., Herbert, M., Hyslop, L., Ahmad, S., Murdoch, A., and Strachan, T. 2004. Derivation of human embryonic stem cells from day-8 blastocysts recovered after three-step in vitro culture. Stem Cells 22: 790-797.

Suss-Toby, E., Gerecht-Nir, S., Amit, M., Manor, D., and Itskovitz-Eldor, J. 2004. Derivation of a diploid human embryonic stem cell line from a mononuclear zygote. Hum. Reprod. 19: 670-675.

Takahashi, T., Lord, B., Schulze, P.C., Fryer, R.M., Sarang, S.S., Gullans, S.R., and Lee, R.T. 2003. Ascorbic acid enhances differentiation of embryonic stem cells into cardiac myocytes. Circulation 107: 1912-1916.

Thomson, J.A., Itskovitz-Eldor, J., Shapiro, S.S., Waknitz, M.A., Swiergiel, J.J., Marshall, V.S., and Jones, J.M. 1998. Embryonic stem cell lines derived from human blastocysts. Science 282: 1145-1147.

Veiga, A., Camarasa, M.V., Aran, B., Raya, A., and Izpisúa Belmonte, J.C. 2007. Selection of embryos for stem cell derivation: Can we optimize the process? In Stem cells in reproductive medicine: Basic science and therapeutic potential (ed. C. 
Simon and A. Pellicer), pp. 133-145. Informa, London.

Veiga, A., Torello, M.J., Boiso, I., Sandalinas, M., Busquets, A., Calderon, G., and Barri, P.N. 1995. Optimization of implantation in the in-vitro fertilization laboratory. Hum. Reprod. (suppl. 2) 10: 98-106.

Verlinsky, Y., Strelchenko, N., Kukharenko, V., Rechitsky, S., Verlinsky, O., Galat, V., and Kuliev, A. 2005. Human embryonic stem cell lines with genetic disorders. Reprod. Biomed.
Online 10: 105-110.

Xu, C., Police, S., Rao, N., and Carpenter, M.K. 2002. Characterization and enrichment of cardiomyocytes derived from human embryonic stem cells. Circ. Res. 91: 501-508.

Zhang, X., Stojkovic, P., Przyborski, S., Cooke, M., Armstrong, L., Lako, M., and Stojkovic, M. 2006. Derivation of human embryonic stem cells from developing and arrested embryos. Stem Cells 24: 2669-2676. 